\title{
ATTITUDES OF SLOVENIAN LANGUAGE USERS TOWARDS GENERAL MONOLINGUAL DICTIONARIES: AN INTERNATIONAL PERSPECTIVE
}

\section{Iztok KOSEM}

Centre for Language Resources and Technologies, University of Ljubljana (Faculty of Arts)

\section{Sascha WOLFER}

Institut für Deutsche Sprache, Mannheim

\section{Robert Lew}

Adam Mickiewicz University, Poznań

\section{Carolin Müller Spitzer}

Institut für Deutsche Sprache, Mannheim

Kosem, Iztok, Wolfer, Sascha, Lew, Robert, Müller-Spitzer, Carolin. (2018): Attitudes of Slovenian Language Users Towards General Monolingual Dictionaries: an International Perspective. Slovenščina 2.o, 6 (1): 90-134.

DOI: http://dx.doi.org/10.4312/slo2.0.2018.1.90-134.

This paper presents the results of a survey on dictionary use in Europe, the largest survey of dictionary use to date with nearly 10,000 participants in nearly thirty countries. The paper focuses on the comparison of the results of the Slovenian participants with the results of the participants from other European countries. The comparisons are made both with the European averages, and with the results from individual countries, in order to determine in which aspects Slovenian participants share similarities with other dictionary users (and non-users) around Europe, and in which aspects they differ. The findings show that in many ways the Slovenian users are similar to their European counterparts, with some noticeable exceptions, including (much) stronger preference for digital dictionaries over print ones, above-average reliance on other people when dictionary does not contain the relevant information, and the largest difference between the price of a dictionary and the amount willing to spend on it. 
Keywords: user research, dictionary use, general monolingual dictionary, attitudes towards dictionaries, lexicography, international comparison

\section{INTRODUCTION}

Dictionary use research has a long tradition, however, most of the existing studies are focused on dictionaries of English, especially learners' dictionaries of English. One of the main shortcomings of the existing studies is that their subjects are often university students (of linguistics) and language professionals, whereas other user groups tend to be neglected (cf. Bogaards 2003, Tarp 2009, Müller-Spitzer 2014, Lew 2015). Moreover, monolingual dictionaries have rarely been in the spotlight (Klosa et al. 2014 is one exception). Another problem is that dictionary use is not equally researched across Europe; there are countries with a vast amount of research on the one side, and countries where no or hardly any studies of dictionary use have been done on the other.

In an attempt to start filling some of these gaps, a Europe-wide survey on dictionary use was conducted in 2017, supported by the European Network of e-lexicography (ENeL; EU COST Action IS1305). ${ }^{1}$ The survey was conducted in 29 different countries, including Slovenia, by 58 researchers. The survey focussed on monolingual dictionaries and tried to reach as many different user groups as possible, even those users who do not use dictionaries at all, by using a variety of dissemination channels and being translated into multiple languages.

Preliminary results of the survey were presented at the eLex conference in 2017 (Kosem et al. 2017), and a more in-depth analysis is offered in Kosem et al. (2018). These two reports focus on the overall results of the survey and thus provide a general picture of dictionary use and attitudes towards (monolingual)

\footnotetext{
${ }^{1}$ Website: http://www.elexicography.eu/events/european-survey-on-dictionary-use/.
} 
dictionaries by the participants, and in some aspects offer specific comparisons between the participants from different countries involved in the survey.

This paper takes a closer look at the survey results of the Slovenian participants, focussing on the comparison with the results from the participants in other European countries. The main objective of the paper is to identify similarities and differences in dictionary use and attitudes towards dictionaries, both overall and for individual questions. The paper also attempts to determine certain patterns, considering not only the survey results, but also the state-ofthe-art of lexicography in respective countries.

The analysis described in this paper is complementary to the analysis conducted by Arhar Holdt (2018) that focused exclusively on the results of the Slovenian participants. Together, the studies make a considerable step towards filling the gap in the research into the use of Slovenian dictionaries, which has been pointed out by various researchers over the years (cf. Rozman 2004, Stabej 2009, Logar 2009, Arhar Holdt 2015, Arhar Holdt et al. 2016). Admittedly, there has recently been a noticeable increase of interest in such studies, especially in the field of monolingual lexicography, mainly on the account of proposals for a new general monolingual dictionary of Slovene (Krek et al. 2013, Gorjanc et al. 2015, Gliha Komac et al. 2015, Gorjanc et al. 2016,). In 2017, a large-scale national survey on the use of and expectations from language resources (Gliha Komac 2017), completed by over 5953 participants (3204 in full), was conducted, but unfortunately due to severe methodological shortcomings and bias (cf. Logar et al. 2017), the results have very limited value.

Interestingly, in nearly all other countries participating in the survey, dictionary use research is as underdeveloped as in Slovenia, or is even non-existent. There are some notable exceptions such as the UK, and to a lesser extent Denmark and Germany. Yet, the trend in most of the countries is positive as, in addition to this survey, other studies have appeared in recent years. 
The information on the status of dictionary use research was part of the reports submitted by local partners, ${ }^{2}$ which used the same template with instructions to ensure the comparability of information provided. The reports also provided information on state-of-the-art of (monolingual) lexicography in each country (summarized briefly in the next paragraphs), which is essential in interpreting the results of any comparative analyses, including the ones conducted in this paper. For example, Slovenia is one of few countries (others are Estonia, Finland, and Georgia) where only a single monolingual dictionary (in one or more editions) is available. Furthermore, Slovenia is one of the countries (others include Croatia, the Czech Republic, Germany, Portugal, and Sweden) where spelling dictionaries are considered to represent the language norm, whereas in countries such as Austria, Finland etc. this role is taken by general monolingual dictionaries. And while in Slovenia and many countries dictionaries in digital format are predominant and most popular among the users, there are still several countries where paper dictionaries dominate. 3

An indication of the advanced status of Slovenia in monolingual lexicography is also the fact that two born-digital dictionaries are currently planned and/or being made, a situation found in very few countries (Netherlands, Poland, the Czech Republic, and Croatia). On the other hand, in countries such as Romania and Serbia, lexicographic efforts are directed at retro-digitizing existing printed dictionaries.

In Slovenia, as in many other countries with a relatively small number of native speakers, monolingual dictionaries are compiled and published by public institutions. On the other hand, commercial publishers dominate over public institutions in Greece, Germany, France, Israel, Italy, Portugal, and the UK. In

\footnotetext{
${ }^{2}$ Some of these reports are available as Supplements of Kosem et al. (forthcoming), and some are published in the same issue of Slovenščina 2.O as this paper.

3 In fact, in Serbia, general monolingual dictionaries in digital format did not even exist at the time of survey.
} 
Denmark, Ireland, and the Netherlands, where publicly funded dictionaries are dominant, commercial publishers still play an important role. Finally, in Croatia and Norway, commercial publishers of monolingual dictionaries are sometimes partly or entirely funded with public money.

As can be seen, in this diverse European lexicographic landscape, Slovenia is similar and/or different to different countries in different areas of (monolingual) lexicography. As our analysis will show, these similarities and differences sometimes, but not always, directly translate into participants' responses.

\section{THE SURVEY}

The idea behind our survey was to gather information about dictionary use from as many EU countries as possible, plus a few non-member countries with close cultural ties to Europe and with active members in the ENeL network.

We aimed at a large number of participants, so well-thought-out promotion was of the essence. An important part of this process was the decision to have the survey translated into local languages of participating countries, which was the task of the local partners. The survey was then promoted internationally, as well as within participating countries, using a variety of channels, such as mailing lists, social networks, emails to institutions and individuals, personal contacts, media announcements etc.

In order not to discourage participants from completing the survey, it was essential that the survey did not take a lot of their time. A natural consequence of this assumption was that we needed a fairly small number of carefully selected questions. Thus, the participants were asked to answer only 13 questions that formed the general part of the survey. These questions were accompanied by 11 questions eliciting personal data from the participants. Some local partners also opted to add the local part, which included up to five questions related to their research interests and was presented to participants 
from their respective countries only. In constructing the survey, the group consulted a number of experts, including an expert on social survey methods. The survey was also piloted among students at the University of Mannheim and University of Ljubljana.

The most central research aim was to probe the usage patterns of, and attitudes towards, general monolingual dictionaries. At the same time, we kept the participants' options open as far as the medium of the dictionary was concerned, acknowledging that there might be substantial differences across the countries in this respect: some might have largely adopted the newer digital formats, while others would still embrace print.

In formulating the survey items, we were aiming to make it possible to compare countries, as well as measure the effects of participant age and background. With this assumption, the items had to make sense to a broad audience across a diverse spectrum of languages and cultures. In a similar vein, we were aware of the gap in previous research relating to the fact that surveys have tended to capture participants as dictionary users, but virtually no surveys have sought responses from people who did not use dictionaries. We did want a representation of the latter group in our survey, challenging as this might be. A natural consequence of this assumption was that the survey could not be too long, and should not assume detailed knowledge about dictionaries on the part of the participants.

The decisions to address a broad audience and use the same questions in different countries to enable comparisons unavoidably resulted in certain shortcomings. Some, which have been commented on from the Slovenian perspective but probably apply to other countries as well, have already been pointed out by Arhar Holdt (2018), for example the use of a very broad 
definition of a general monolingual dictionary, 4 and offering multiple fields to the Slovenian participants for listing monolingual dictionaries they use, despite the fact that only one monolingual dictionary of Slovene (in two editions) was available at the time. Arhar Holdt (2018) points out that this led to the participants' incorrect interpretation of the question, as they were listing other resources such as spelling dictionaries, terminological dictionaries, phraseological dictionaries, dictionary portals (as opposed to specific dictionaries), corpora, etc. Similar problems with off-target responses to this particular question were also observed in several other countries. 5 In this particular case, the findings are in line with what the survey question aimed to elicit, namely identify not only the main general monolingual dictionaries used but also other resources that the participants consider as containing similar types of information about language. ${ }^{6}$

\section{SURVEY RESULTS}

The survey was open from 8 May to 9 July 2017. It was completed by 9562 participants.7 Slovenia was fourth among all the participating countries in terms of the number of participants with 619 completed questionnaires (Figure 1), and second, after Estonia, in completed questionnaires per million population (Table 1).

\footnotetext{
4 The definition was: "A general monolingual dictionary of [language] describes [language] words using [language] explanations. There is no other language involved. In such a dictionary you can find most commonly used words." We believe this option was much better than trying to come up with a more detailed definition, which would perhaps satisfy lexicographers and linguists but would very likely confuse the survey participants.

5 The information was obtained verbally from local partners, and in some cases, based on preliminary analyses of local data (e.g. Croatia, Spain).

${ }^{6}$ This value of survey results is conceded also by Arhar Holdt (2018: 4).

7 Each participant could only complete the survey once.
} 


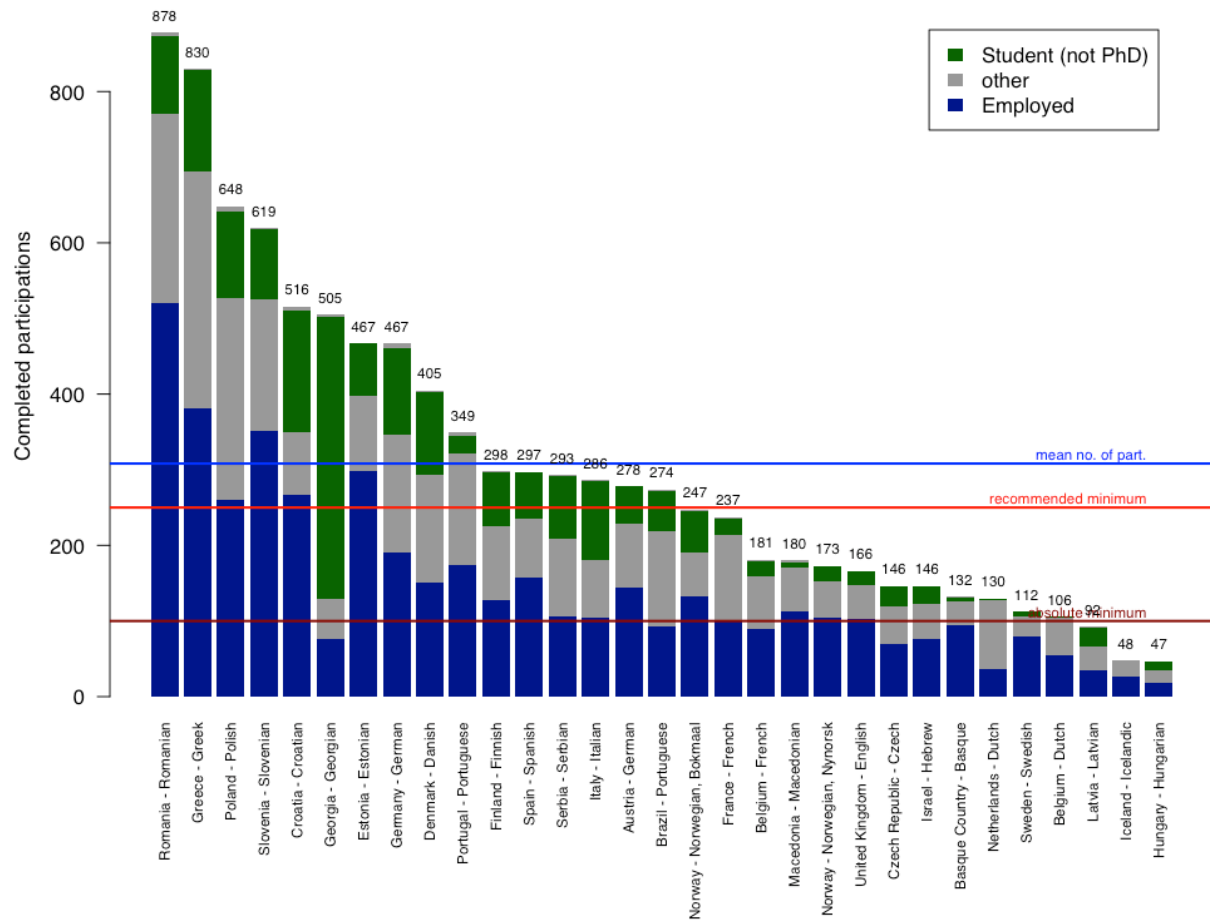

Figure 1: Survey participants per country, divided by type of participant.

\begin{tabular}{|c|c|c|c|c|c|}
\hline Country & $n$ & $\begin{array}{l}\text { Participants } \\
\text { per million }\end{array}$ & Country & $n$ & $\begin{array}{c}\text { Participants } \\
\text { per million }\end{array}$ \\
\hline Romania & 878 & $44 \cdot 55$ & Serbia & 293 & 41.52 \\
\hline Greece & 829 & 77.12 & Belgium & 286 & 25.20 \\
\hline Poland & 649 & 17.10 & Italy & 285 & $4 \cdot 7$ \\
\hline Slovenia & 619 & 299.76 & Brazil & 274 & 1.32 \\
\hline Croatia & 516 & 123.71 & Austria & 268 & 30.64 \\
\hline Georgia & 507 & 136.36 & France & 238 & 3.56 \\
\hline Germany & 479 & $5 \cdot 79$ & Macedonia & 181 & 86.98 \\
\hline Estonia & 467 & 354.86 & UK \& Ireland & 169 & 2.34 \\
\hline
\end{tabular}




\begin{tabular}{l|r|c|r|r}
\hline Norway & 420 & 80.26 Czech Rep. & 146 & 13.83 \\
\hline Denmark & 405 & 70.67 Israel & 146 & 16.48 \\
\hline Portugal & 349 & 33.82 Basque Cnt. & 132 & 60.27 \\
\hline Finland & 298 & 54.23 Netherlands & 130 & 7.64 \\
\hline Spain & 297 & 6.38 Sweden & 112 & 11.31 \\
\hline
\end{tabular}

Table 1. Completed surveys per million population (Source of population data: Wikipedia and World Bank 2016)

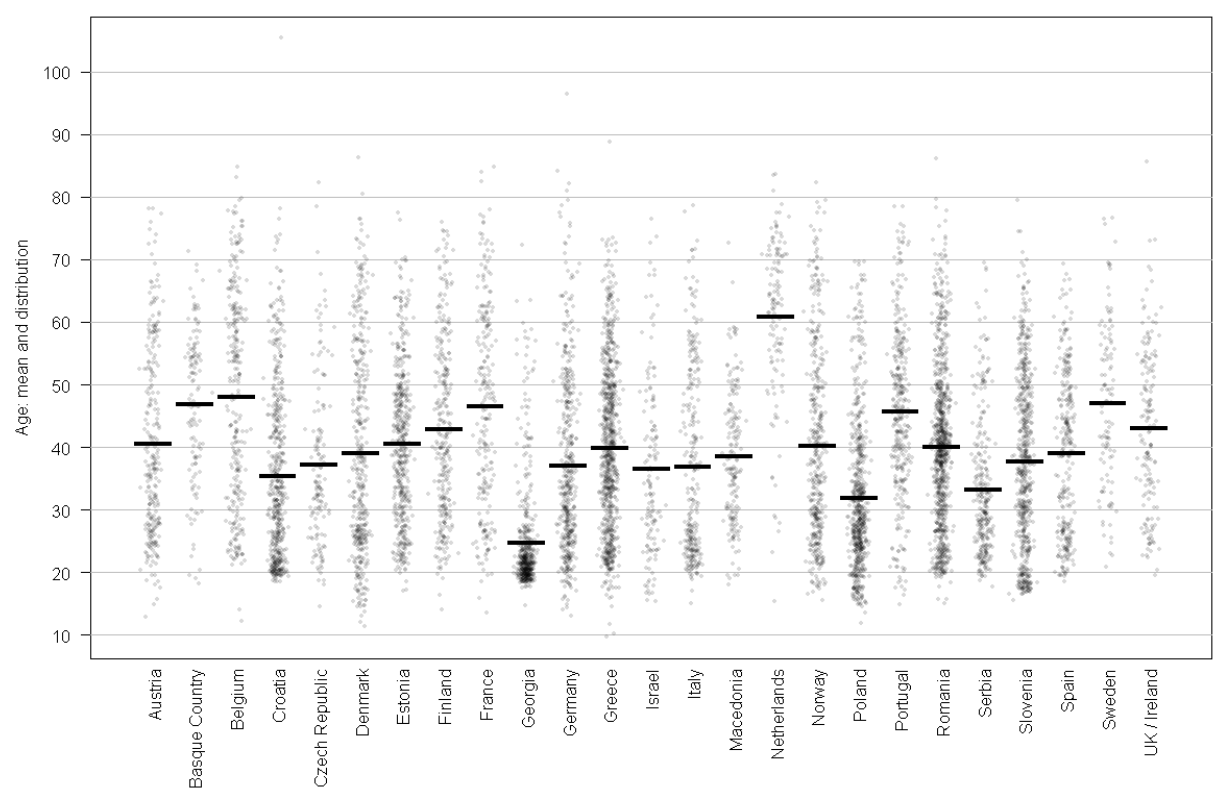

Figure 2: Age of participants (mean and distribution) per country.

As Figure 1 shows, the aim of getting a heterogeneous sample of participants in each country was achieved. ${ }^{8}$ Furthermore, in all the countries, with the notable exception of Georgia, students represented only a small portion of the total participants, meaning that the survey overcomes some of the shortcomings of

${ }^{8}$ For a detailed analysis of the sample, see Kosem et al. (2018). 
the existing research where students have dominated the sample. Figure 2 shows the age distributions and the mean age of the participants in each country. The grand mean is 38.8 years, which is close to the mean age of the participants from Slovenia (37.6 years). The most notable outliers are the Netherlands (mean age of 60.9 years) and Georgia (24.7 years). However, it has to be noted that drawing heterogenous samples also introduces a certain caveat. In the present paper, we are comparing samples from countries and not countries per se. As a consequence, the differences we report cannot be explained by country-specific variables alone but could always be - at least to a certain extent - explained by differences in sample composition across countries.

For the purposes of our analyses, we excluded the data for Brazil as a nonEuropean country, ${ }^{9}$ as well as for three countries (Hungary, Iceland and Latvia) that failed to reach the required minimum of 100 completed questionnaires. Consequently, the analyses was conducted on 9.099 questionnaires.

In the following sections we present the results of the survey, dividing them into thematic subsections, and then discuss the main findings, paying particular attention to the comparisons of the responses from Slovenian participants with those from the whole sample, or from individual countries. The survey questions are provided as titles of figures and tables.

\subsection{DICTIONARY USE}

The results for the questions about the use of dictionaries in general and about the use of general monolingual dictionaries show that the habits of the Slovenian participants are very similar to the European averages (Figures 3 and 4). There were also no noticeable differences in terms of demographic variables such as age group, gender and so forth.

9 We kept the Israel data due to its close connections with EU, including participation in actions such as ENeL. 


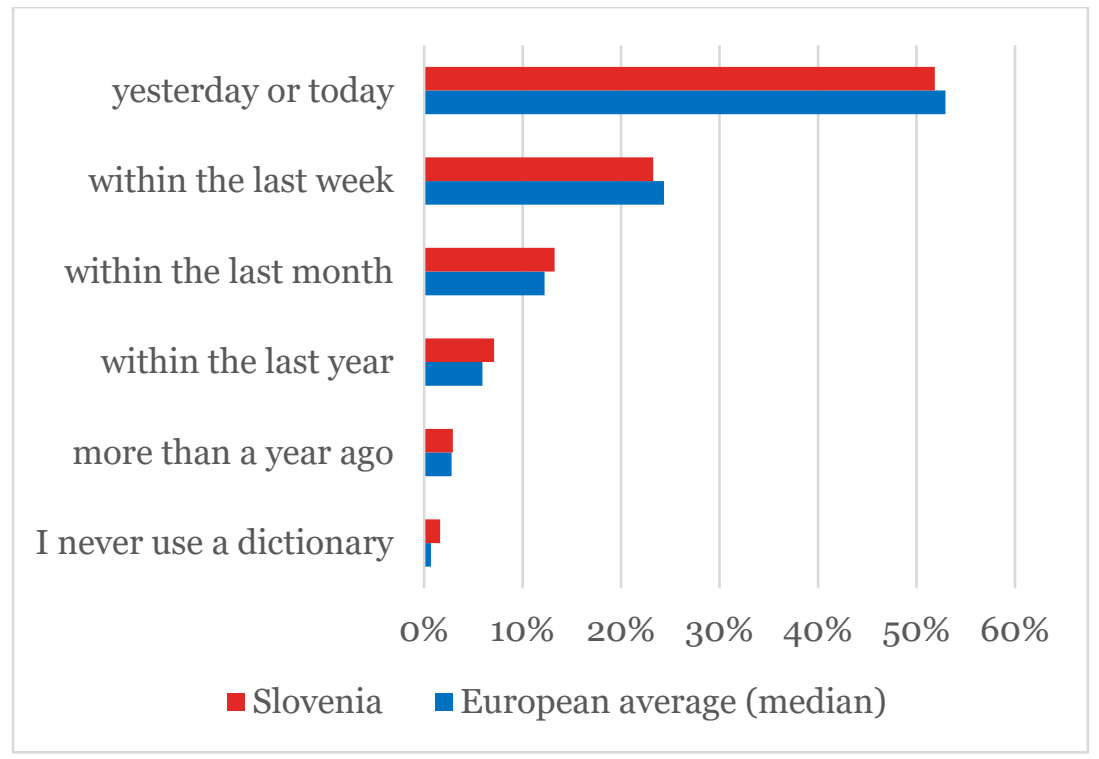

Figure 3: When was the last time you used a dictionary?

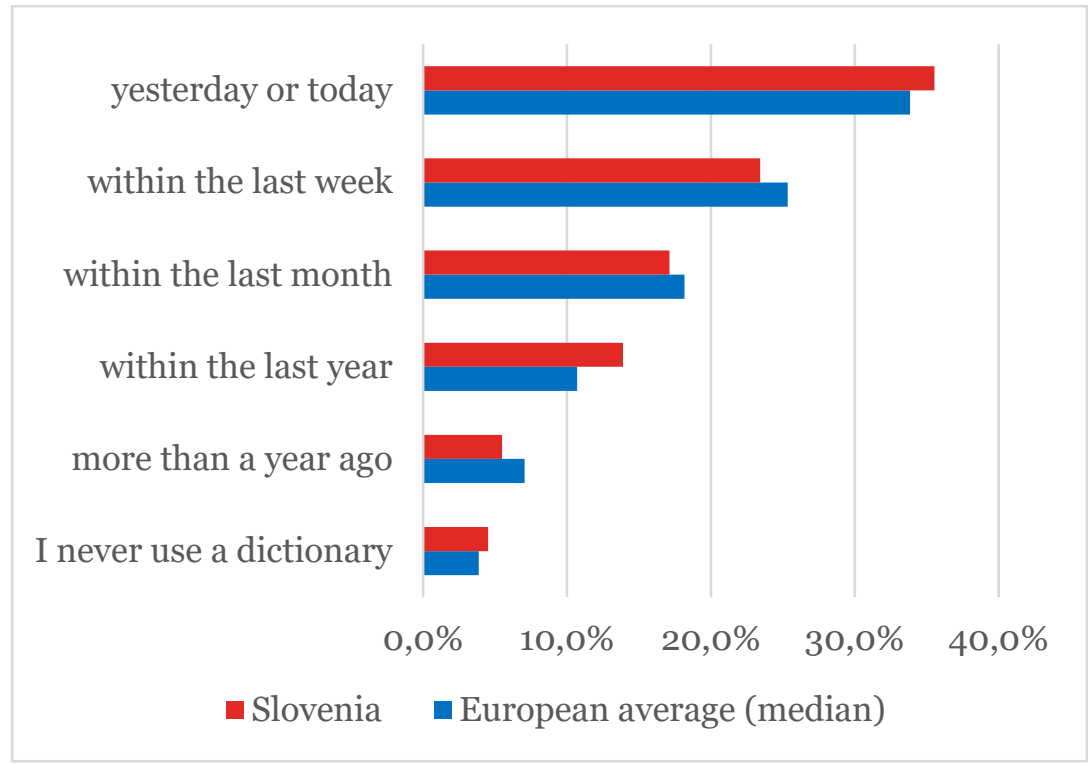

Figure 4: When was the last time you used a monolingual dictionary? 
The picture is more varied when comparing Slovenia with individual countries. In terms of monolingual dictionary use in the last week (European median was 59.8\%), similar to the Slovenian participants (59\%) were participants from the Basque Country (+o.8 percentage points; hereinafter p.p. ${ }^{10}$ ), Austria (+1.1 p.p.), Belgium (-1.7 p.p.), Spain (-2.1 p.p.), Portugal (+2.6 p.p.), Finland (-4 p.p.) and Germany (+4.5 p.p.). Monolingual dictionaries were used in the last week by a markedly higher proportion of participants in Denmark (+15.3 p.p.), Romania (+14.3 p.p.), Norway (+12.7 p.p.), France (+9.1 p.p.), and the UK and Ireland (+9 p.p.). On the other hand, the countries with the highest percentages of participants that reported not using monolingual dictionaries at all are Croatia (20\%), Macedonia (16.6\%), Serbia (17.4\%), and Georgia (14.8\%).

\subsection{Situations of dictionary use}

The distribution of selected answers of the Slovenian participants about the situations in which they used monolingual dictionaries (more than one answer could be selected) was not considerably different from the European averages (Figure 5). Nonetheless, some differences could be observed: the Slovenian participants in general, if compared to the European averages, used monolingual dictionaries in all the situations listed more often, especially when writing assigned work (+13.9 p.p.), correcting someone else's text (+11.3 p.p.), playing word games (+9.4 p.p), reading official documents (+9.1 p.p.), and writing official documents (+4.5 p.p.). The only situation in which the Slovenian participants reported below average use was writing emails, posts or letters (-4 p.p.).

10 Percentage points are used when comparing data of different countries, as the number of participants per country differs. 


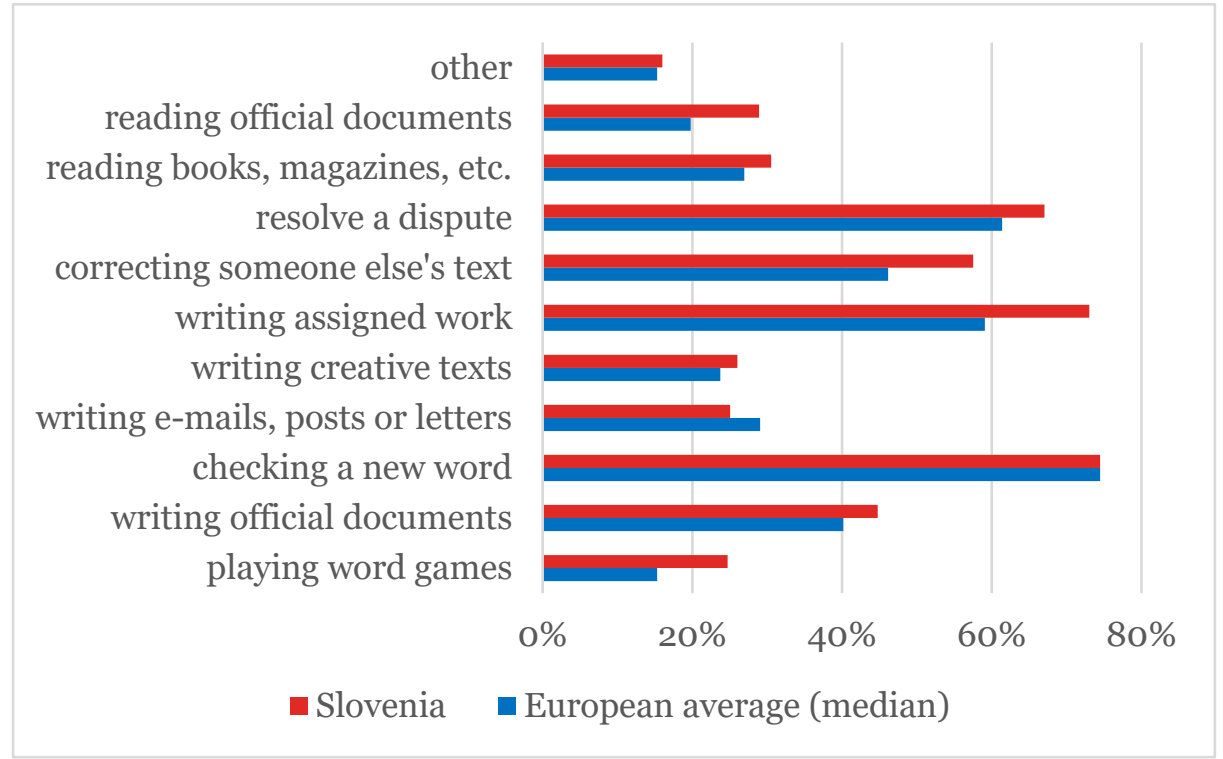

Figure 5: In which of the following situations did you use a monolingual X dictionary? The comparison of Slovenia with individual countries in terms of situations of dictionary use shows that overall the Slovenian participants were most similar to the participants from Denmark (4 rank differences ${ }^{11}$ ) and Estonia (5 rank differences), with the only considerable differences found in the percentages of participants writing emails, posts or letters (Denmark +20.4 p.p., Estonia +18 p.p.). Fairly similar to the Slovenian participants were also the participants from Greece, Germany, Norway, Poland and Romania (6 rank differences).

On the other hand, the Slovenian participants differed the most in the situations of monolingual dictionary use from the participants from Israel and Serbia (12 rank differences), Croatia (11 rank differences), and Georgia, Macedonia, and Portugal (10 rank differences).

${ }^{11}$ Rank difference is used mainly when comparing the results of questions with multiple
answers. The countries are ranked according to the level of dissimilarity with Slovenia. 


\subsection{Meaning of a monolingual dictionary for the community and individuals}

Several questions asked about what a monolingual dictionary meant to the community in general and to the participants. The first question asked the participants what in their opinion a monolingual dictionary represented to the people (more than one answer was allowed). As the comparison between the Slovenian participants and the European averages (Figure 6) shows, the Slovenian participants (significantly) differ from the averages at the statements that a dictionary represents an exhaustive knowledge of language (+16.4 p.p.), a national symbol (+14.2 p.p.), and that it is useful for the general public (+6.5 p.p.). On the other hand, the below average share of Slovenian participants selected options that a dictionary represents an authority (-8.5 p.p.) and that it is useful for children (-8.4 p.p.).

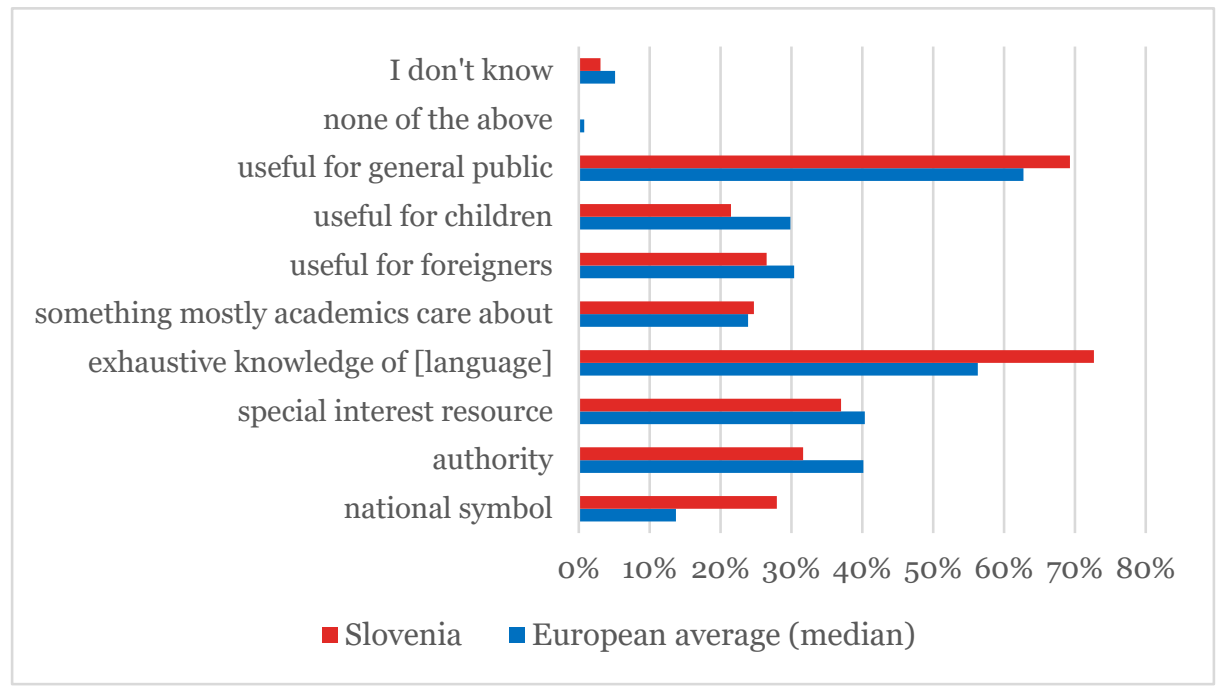

Figure 6: Which characteristics do people associate with the leading monolingual dictionary in [your country]?

Most similarities in the distribution of responses for this question can be found between the Slovenian participants and the participants from Serbia (5 rank differences), Georgia and Germany (6 rank differences), and Croatia (7 rank 
differences). The largest differences to the Slovenian participants is found at the participants from the Czech Republic (12 rank differences), Finland and France (11 rank differences), and the Netherlands, Portugal, and the UK and Ireland (10 rank differences).

A separate question asked the participants what they would do if they found a dictionary left behind by a relative. As shown in Figure 7 , the Slovenian participants responses were very similar to the European averages, with most of the participants indicating that they would keep the dictionary. However, the Slovenian participants differ from the European averages in their reasons for keeping the dictionary: a larger percentage of Slovenian participants would keep the dictionary because it belonged to their relative (+10.4 p.p.), and a smaller percentage would keep the dictionary in order to use it (-5.1 p.p.). The differences can be mainly attributed to the differences in answers by age group, as the younger generations of Slovenian participants (up to 26 years old) showed most noticeable deviations, with the percentages for both aforementioned answers being fairly similar (32\% and $37 \%$ respectively).

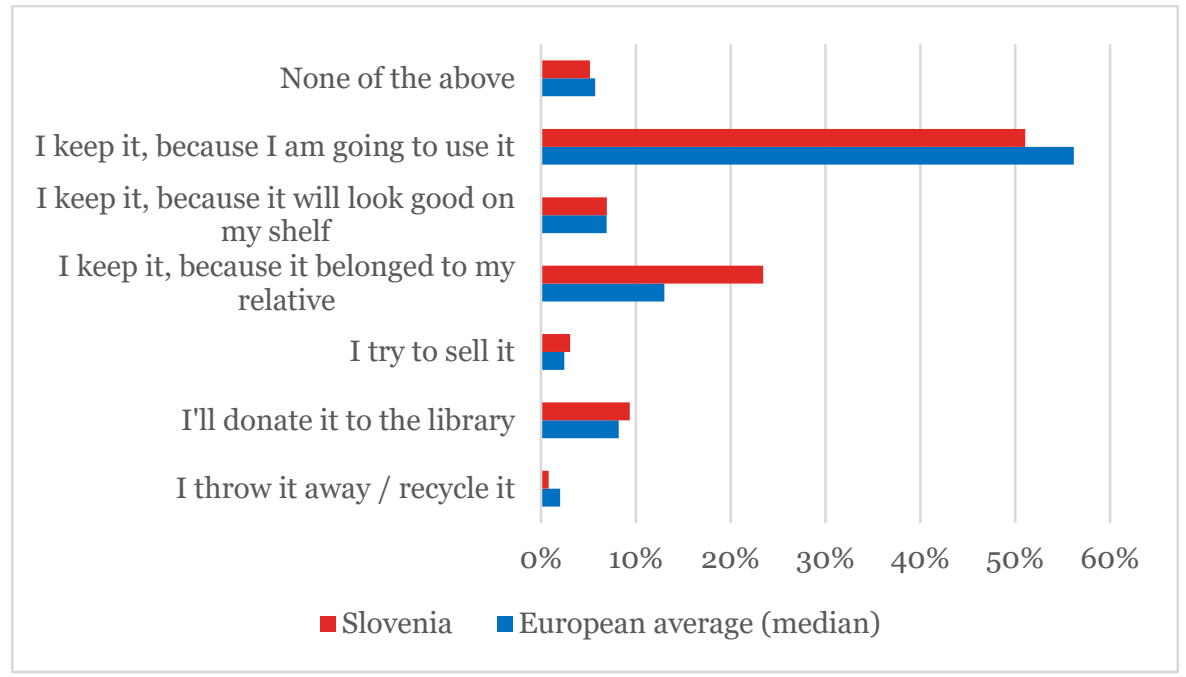

Figure 7: Imagine the following situation: You are cleaning out a relative's house; there you find a well-known monolingual dictionary of [language]. What do you do? 
Slovenia is also among the countries with the lowest percentage of participants that reported they would throw the dictionary away or recycle it (o.8\%).

For the comparisons with individual countries we have conflated the answers into three broader categories of participants' actions: getting rid of the dictionary; keeping the dictionary but not using it; keeping the dictionary and using it. The results are shown in Table 2. In each of the three categories, we have marked the three countries with the highest percentage of participants in grey, and the three countries with the lowest percentage of participants in red. As can be seen, Slovenia is among the top three countries in the percentage of participants most likely to keep the dictionary, but not use it. In the other two categories, the percentage of Slovenian participants is below the European averages (get rid: -4.4 p.p.; keep and use it: -5.1 p.p.). The highest percentages of participants that would use the dictionary are noted for Serbia, Macedonia, and Portugal. On the other hand, Belgium, Finland, and Denmark stand out with very high percentages of participants that would get rid of the dictionary.

The comparison based on the basis of the three aforementioned categories shows that the Slovenian participants are very similar to the participants from Spain (2 rank differences), Norway (3 rank differences), Italy (4 rank differences) and France (5 rank differences). On the other hand, the answers of Slovenian participants differ the most from the answers of the participants from Serbia (15 rank differences), Macedonia (14 rank differences), Finland and Greece (13 rank differences), and Portugal and Romania (12 rank differences).

\begin{tabular}{|l|r|r|r}
\hline & getting rid of & \multicolumn{2}{|l}{$\begin{array}{l}\text { keeping but not } \\
\text { using }\end{array}$} \\
\hline median & $17.6 \%$ & $21.9 \%$ & $56.2 \%$ \\
\hline Slovenia & $13.2 \%$ & $30.4 \%$ & $51.1 \%$ \\
\hline Austria & $20.5 \%$ & $20.9 \%$ & $48.9 \%$ \\
\hline Basque Country & $6.8 \%$ & $19.7 \%$ & $65.9 \%$ \\
\hline
\end{tabular}




\begin{tabular}{|c|c|c|c|}
\hline Belgium & $30.1 \%$ & $26.6 \%$ & $34.6 \%$ \\
\hline Croatia & $11.4 \%$ & $22.3 \%$ & $62.2 \%$ \\
\hline Czech Republic & $17.8 \%$ & $21.9 \%$ & $56.2 \%$ \\
\hline Denmark & $28.4 \%$ & $22.5 \%$ & $44.7 \%$ \\
\hline Estonia & $20.1 \%$ & $22.5 \%$ & $41.1 \%$ \\
\hline Finland & $28.5 \%$ & $10.7 \%$ & $57.4 \%$ \\
\hline France & $20.6 \%$ & $23.5 \%$ & $49.6 \%$ \\
\hline Georgia & $2.6 \%$ & $33.7 \%$ & $58 \%$ \\
\hline Germany & $27.6 \%$ & $23.8 \%$ & $40.1 \%$ \\
\hline Greece & $8.7 \%$ & $11.7 \%$ & $71.2 \%$ \\
\hline Israel & $27.4 \%$ & $14.4 \%$ & $54.1 \%$ \\
\hline Italy & $10.2 \%$ & $27.7 \%$ & $57.5 \%$ \\
\hline Macedonia & $8.8 \%$ & $8.8 \%$ & $81.2 \%$ \\
\hline Netherlands & $22.3 \%$ & $25.4 \%$ & $43.8 \%$ \\
\hline Norway & $17.6 \%$ & $24.8 \%$ & $47.6 \%$ \\
\hline Poland & $10.8 \%$ & $21.3 \%$ & $64.1 \%$ \\
\hline Portugal & $8.9 \%$ & $12.6 \%$ & $74.5 \%$ \\
\hline Romania & $19.2 \%$ & $10.3 \%$ & $66.3 \%$ \\
\hline Serbia & $6.5 \%$ & $8.9 \%$ & $82.3 \%$ \\
\hline Spain & $11.8 \%$ & $24.2 \%$ & $53.2 \%$ \\
\hline Sweden & $16.1 \%$ & $16.1 \%$ & $56.3 \%$ \\
\hline UK and Ireland & $19.5 \%$ & $20.7 \%$ & $46.7 \%$ \\
\hline
\end{tabular}

Table 2. What would you do with a relatives' dictionary? Three conflated categories of answers.

The last question connected to the attitudes towards monolingual dictionaries asked the participants what they did if they did not find a word in a dictionary 
(more than one answer was allowed). Similarly to the European averages, a considerable proportion of Slovenian participants reported looking up the word on the web, or consulting another/newer resource (Figure 8). However, the Slovenian participants markedly differed from the European average in reporting that they ask other people, with $44.3 \%$ of participants (+18.3 p.p.) choosing this option. A more detailed analysis that took into account the age group variable revealed that in comparison with the European averages, where the percentages of participants per age group were similar at all the answers, in Slovenia younger generations (up to 26 years old) less frequently than the other age groups consulted another resource (-13 p.p.; European average is 60\%), whereas older participants (above 49 years old) more frequently than the other age groups asked other people (+29.3 p.p.; European average is 26.8\%). Also significant in Slovenia was a high percentage of participants under 26 that believed that a word which could not be found in a dictionary was not really a word (+6 p.p.; European average was 9\%).

...the word exists but it is too rare.

...I need to ask other people.

...I need to refer to another/newer resource.

...I need to look it up on the web.

...it is not really a word.

...none of the above applies.

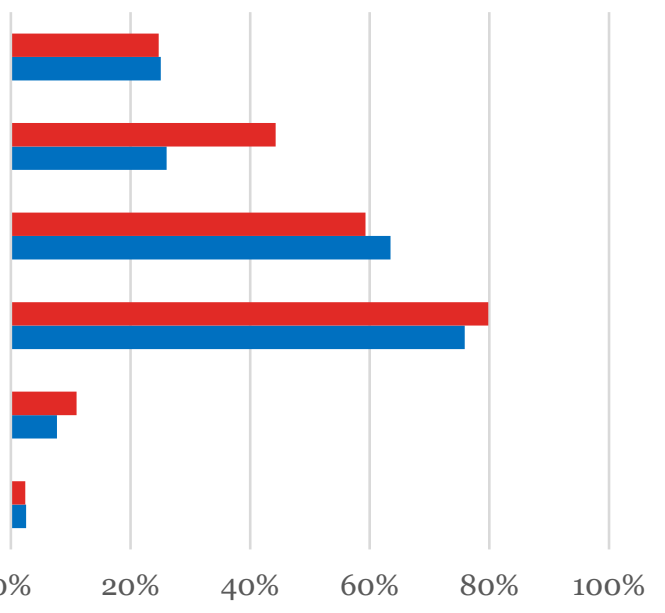

- Slovenia European average (median)

Figure 8: Suppose you encounter a word that is not in a monolingual dictionary, then 
The comparison with individual countries reveals the highest level of similarity between the Slovenian participants and the participants from Estonia, Georgia, Israel, the UK and Ireland (5 rank differences), and Croatia, Czech Republic, Denmark, Finland and Romania (6 rank differences.). It is noteworthy that the differences are often mainly on the account of a higher percentage of Slovenian participants that chose the "ask other people« option. The similarity with Estonia, Georgia, and Finland seems particularly relevant in this case, given that these are the only countries (in addition to Slovenia) where only one general monolingual dictionary (sometimes in various editions) is in use.

On the other hand, the largest differences from the Slovenian participants were exhibited by the participants from Portugal (13 rank differences), Italy (11 rank differences) and Greece (10 rank differences).

\subsection{Dictionary funding}

The survey contained three questions related to dictionary funding. The first one asked the participants whether they supported public funding of general monolingual dictionaries. The second question asked the participants how much they were willing to pay for the dictionary. The third question asked the participants whether they were willing to accept ads in the dictionaries. All three questions allowed the selection of only one of the answers.

As to the issue of whether monolingual dictionaries should receive public funding, the Slovenian participants' opinions were very similar to those in other European countries (Figure 9), as the majority approved of it (96.1\%; European average is $94.5 \%)$. A slightly higher percentage of Slovenian participants (+4.5 p.p.), compared to the European average (33.3\%), pointed to dictionaries helping the public as the reason for their support. 


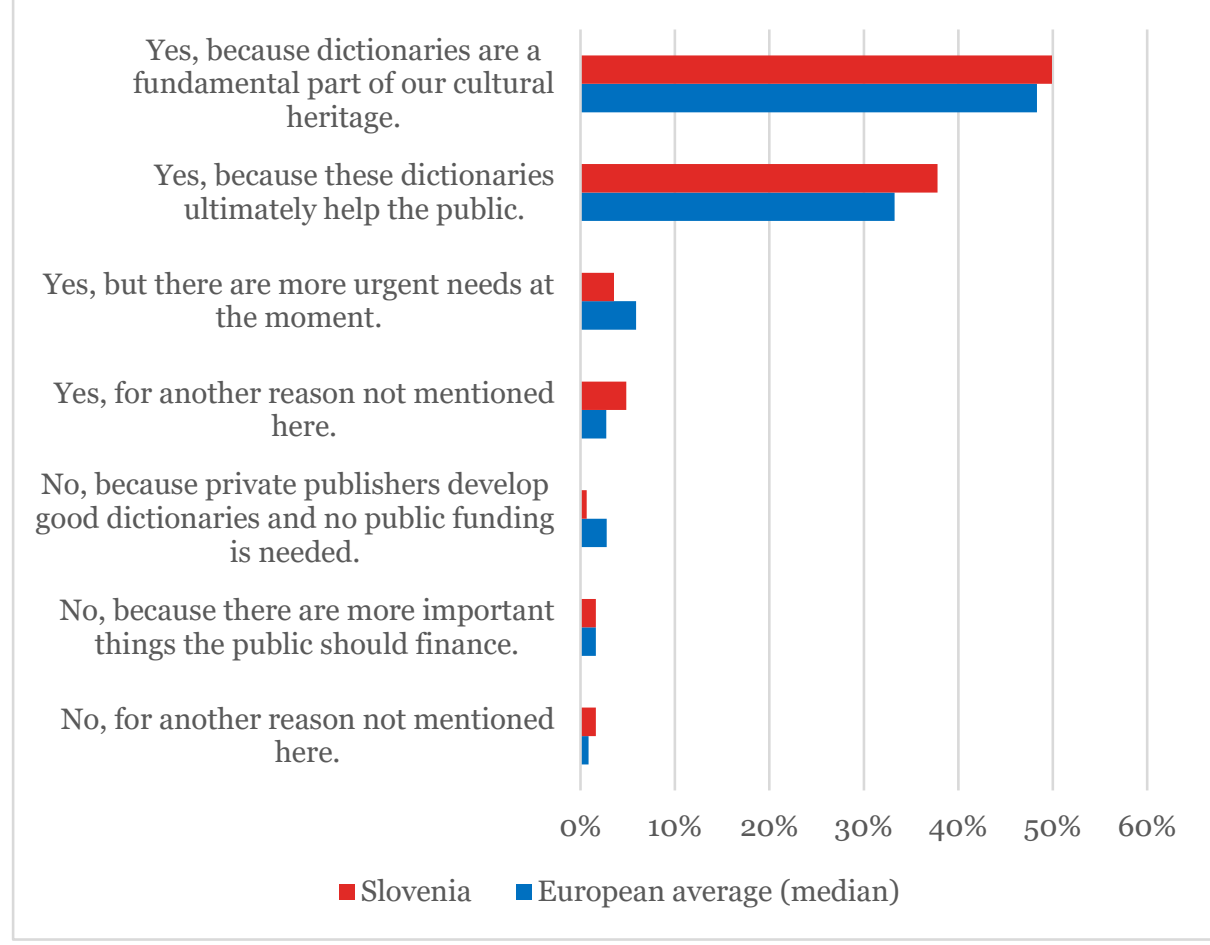

Figure 9: Many monolingual dictionary projects for [language] are financed by the public. Is this a good idea?

When comparing all the answers in individual countries, the Slovenian participants showed the highest level of similarity with the participants from Austria (4 rank differences), the Czech Republic and Finland (5 rank differences), and Poland (6 rank differences). On the other hand, the largest differences were found between the Slovenian participants and the participants from Belgium and Italy (11 rank differences) and the Basque Country (10 rank differences).

If we conflate all Yes and all No answers, the comparison shows a different picture. The highest level of similarity to the Slovenian participants is shown by the participants from Germany (1 rank difference), Denmark, Norway and Sweden (2 rank differences), the Basque Country (3 rank differences), and 
Austria and Estonia (4 rank differences). On the other hand, considerable differences from the Slovenian participants are exhibited by the participants from Israel (19 rank differences), Italy (18 rank differences), the UK and Ireland (17 rank differences), France (16 rank differences), Belgium (15 rank differences) and Georgia (14 rank differences).

Also noteworthy is the fact that the countries where monolingual dictionaries are (predominantly) publicly funded show considerable similarities, with Estonia (98.9\%), Finland (99.0\%), Norway (97.6\%) and Serbia (99\%) standing out with the highest percentages of participants supporting public funding of dictionaries. At the other extreme, Georgia had the highest percentage of participants (10.8\%) that do not support public funding. The lowest support for public funding of dictionaries was found in countries where dictionaries were (in most cases) not publicly funded, namely Israel and Italy (13.7\% against), the UK and Ireland (13.6\%) and France (13.4\%).

At this particular question, differences between the Slovenian participants and the European averages can also be found in the years of education. While the other European countries do not show any major differences due to years of education, a lower than average percentage of the Slovenian participants with over 20 years of formal education (i.e. most educated group of the participants) selected the reason that the dictionaries should be publicly funded because they are part of cultural heritage (-15.5 p.p.; European average was 52.8\%). Similarly, a higher than average percentage of participants with over 18 years of education (+11.5 p.p.; European average was $35.4 \%)^{12}$ selected the reason that the dictionaries help the public.

More differences between Slovenia and the other countries can be found at the question about how much participants are willing to pay for dictionaries in different formats (print, desktop, online and mobile). The results need to be

12 The data includes the median of two groups: participants with 18-20 years of education and those with over 20 years of education. 
interpreted with care due to differences between countries in both economic status and the status of state-of-the-art of (monolingual) lexicography. We tried to optimize the comparison by first converting different currencies to EUR amounts (using conversion rates from 14 July 2017), and then normalising the averages to Slovenia according to the purchasing power parity (PPP). ${ }^{13}$ The results are shown in Figure 10. ${ }^{14}$

13 Purchasing power parity takes into account the purchasing power of the currency and enables comparisons such as how much would people in different countries pay for the same or similar products. The information on PPP was obtained from https://en.wikipedia.org/wiki/List_of_European_countries_by_average_wage (the data spans from 2016 to 2018, depending on the country). For Israel, the data was obtained from https://en.wikipedia.org/wiki/List_of_countries_by_average_wage (we took 1/12 of the average annual salary in 2016). For the Basque Country the data was not available so we used the Spanish data. For United Kingdom and Ireland we used the average of PPP data for both countries.

14 To control for outliers, we excluded $5 \%$ of answers with highest numbers from the analysis. 
60

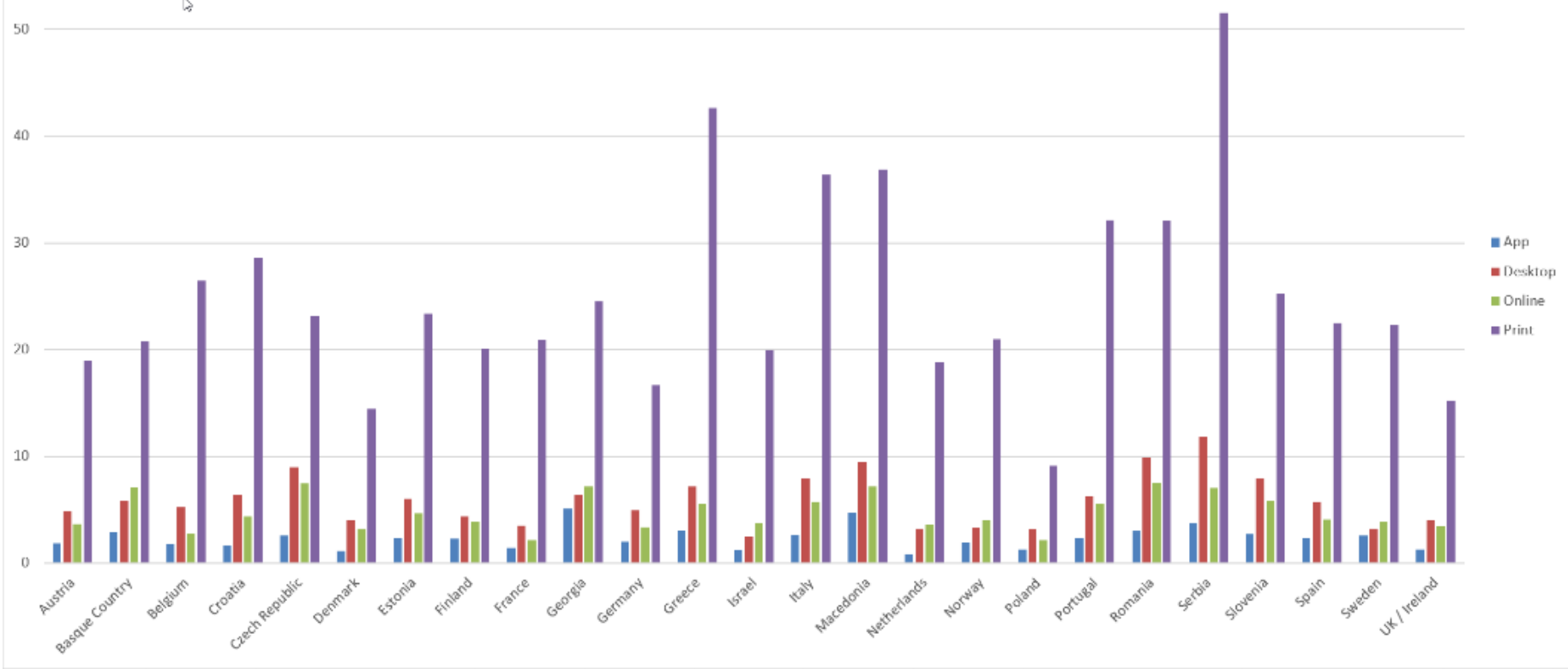

Figure 10: Average amounts (converted to EUR) that the participants were willing to pay for a monolingual dictionary (normalised according to purchasing power parity). 
According to the results, the Slovenian participants are in the top half of the countries in terms of how much they are prepared to pay for a (monolingual) dictionary, regardless of the dictionary format. Overall, the Slovenian participants are very close to the European averages, with the total difference for all four dictionary formats amounting to only 4 rank differences.

In general, the differences between individual countries are very small when it comes to the online and mobile formats of dictionaries. The largest differences between the countries are found for the print format option and, much less noticeably, for the desktop format. For a print dictionary, it is participants from Serbia who were willing to spend the highest portion of their salary (well above the European average; they also stood out when it comes to the desktop format), followed by the participants from Greece, Macedonia, Italy, and Romania. On the other hand, the participants that were prepared to spend on average the smallest portion of their salary on a print dictionary came from Poland, Denmark, and the UK and Ireland.

In Slovenia, 67.2\% participants were against using ads in the online dictionaries, which is noticeably above (+8 p.p.) the European average (59.2\%). Differences between Slovenia and other European countries were also found when comparing them according to age groups. Whereas in European countries on average the willingness to accept ads in dictionaries is dropping with the age of participants (the oldest participants favoured the ads the least), the percentage of the Slovenian participants under 26 that oppose ads (73.2\%) was very similar to the percentage of the participants over 49 (79.5\%).

The comparison with individual countries shows that in most countries the opposition towards ads was similar to that in Slovenia, in Estonia (+12.2 p.p) and France (+17.6 p.p.) it was even much higher. On the other hand, ads were favoured by a high percentage of participants in Georgia (89\%), the Basque Country (63.6\%), Macedonia (62.4\%), and the Czech Republic (57.5\%). 


\subsection{Dictionary format}

The survey contained two questions on dictionary format: the first one asked about typical formats of monolingual dictionaries used (the participants could select more than one answer), and the other one asked about the preferred type of dictionary format (the participants could select only one answer).

The comparison of answers to the first question (Figure 11) shows that as far as tablet and mobile formats are concerned, the habits of the Slovenian participants are very similar to the European averages. More noticeable differences can be observed for the desktop format (the percentage of Slovenian participants is 11.4 p.p. above the European average) and the print format (17.8 p.p. above the European average). The lower percentage of the Slovenian participants using the print format can be mainly attributed to the group of participants under 37 years old (-19.9 p.p.; European average was 49.5\%); the percentage for the group over 50 was in fact very similar to the European average (-2.7 p.p.; European average was 70\%).

Most similar to the Slovenian participants in the use of different dictionary formats were participants from Estonia (2 rank differences), Denmark (4 rank differences) and the Basque Country, Finland, Germany, and the UK and Ireland ( 5 rank differences). Most different to the Slovenian participants were the participants from the Netherlands and Serbia (15 rank differences), Israel (14 rank differences), and Croatia and Sweden (13 rank differences).

If we limit the comparison to digital dictionary formats, we find most similarities between the Slovenian participants and the participants from Estonia (2 rank differences), Germany and the UK and Ireland (3 rank differences), and Finland (4 rank differences). On the other hand, most differences from the Slovenian participants were exhibited by the participants from Croatia and Serbia, (15 rank differences), Israel and the Netherlands (12 rank differences), and Sweden (11 rank differences). The participants from Croatia and Serbia stand out in this comparison, as all digital dictionary formats 
were used by a considerably lower percentage of the participants (below the European averages) compared to the Slovenian participants.

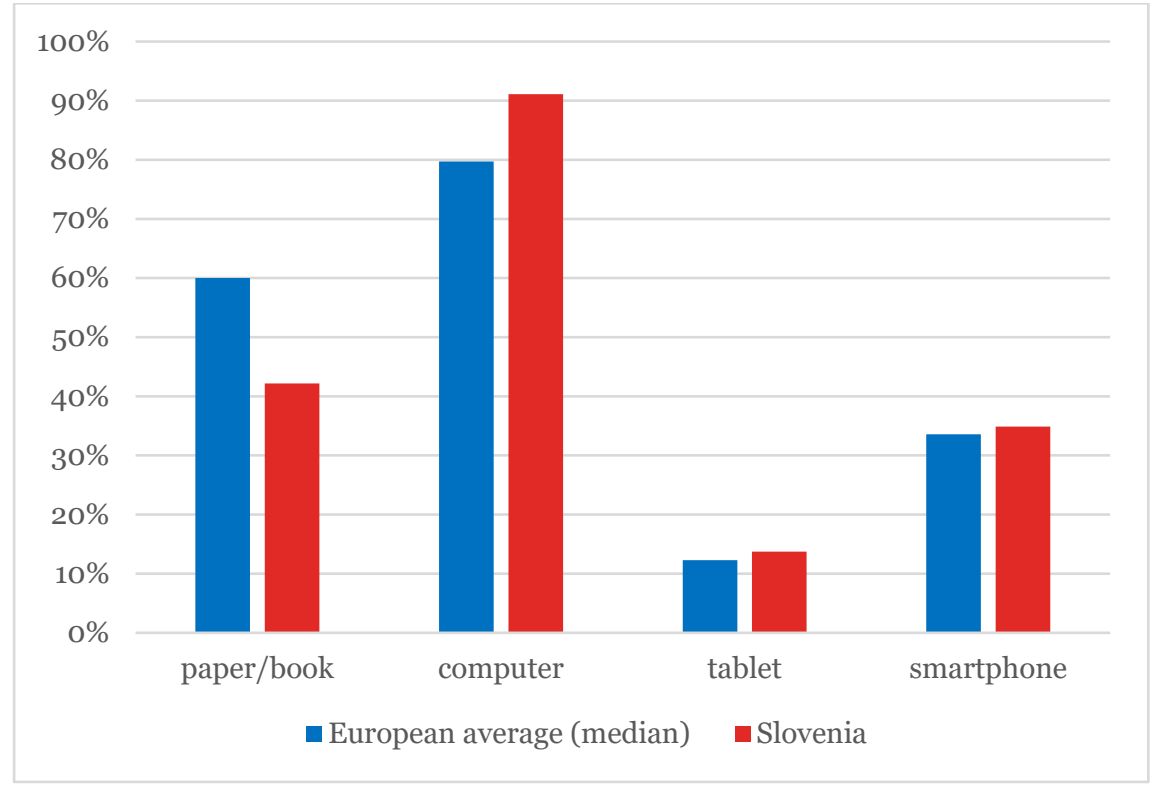

Figure 11: Which format of monolingual dictionaries do you use?

Even more considerable differences between the Slovenian participants and the European averages are found with regard to the preferred dictionary format (Figure 12). The desktop format is preferred by a considerably larger percentage of participants in Slovenia than across Europe (+21.7 p.p.; European average is 26.1\%). On the other hand, the percentage of the Slovenian participants preferring the print format is lower than the European average (-14.2 p.p.; European average is 27.4\%). Also worth noting is a lower percentage of Slovenian participants preferring the mobile format (3.2 p.p. below the European average). Similar to the results of the first format-related question, the differences between the Slovenian participants and the European averages seem to be generationally based, as they were found mainly in the under-50 group (the percentages in the 50-or-over group were more similar to the European averages). 


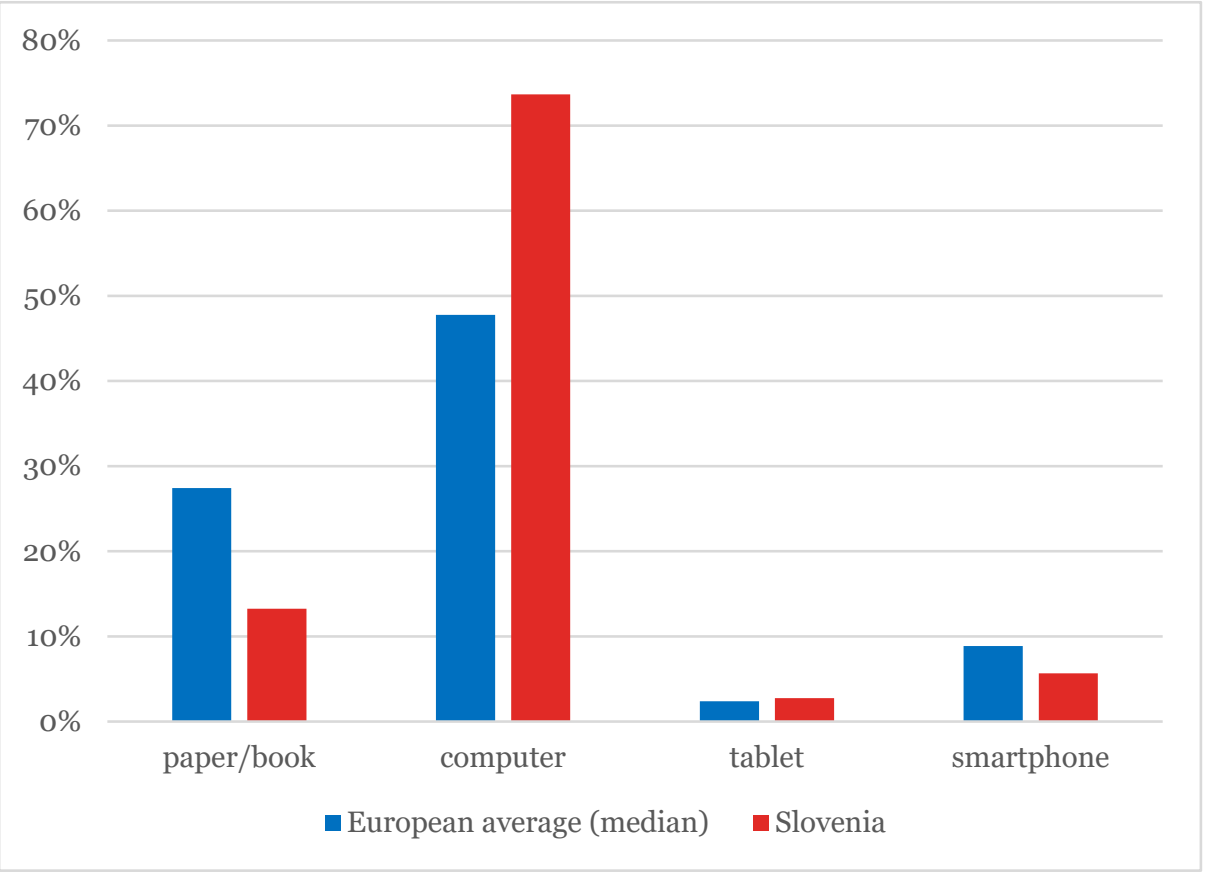

Figure 12: Which format of monolingual dictionaries do you prefer?

In terms of the preferred format, most similar to the Slovenian participants were the participants from the Basque Country (3 rank differences), the Czech Republic, Estonia and Finland (4 rank differences), and Norway (6 rank differences). The differences from participants from all the other countries are more significant, especially compared to Israel (18 rank differences), the Netherlands (16 rank differences), Sweden (14 rank differences), and France, Georgia, Greece, and Serbia (13 rank differences). The highest percentages of preference for different formats were exhibited by participants from Estonia (desktop, 77.1\%), the Netherlands (print, 51.5\%), Sweden (mobile, 33\%), and Denmark (tablet, 5.9\%), respectively.

\subsection{Preferred dictionary characteristics}


The last question in the general part of the survey asked the participants to order the eleven characteristics of a dictionary from the most important to the least important. As shown by the comparison in Figure 13, the Slovenian participants' preferences are very similar to the European average: the most important characteristic is reliable content, followed by up-to-datedness, ease of use and free access (the Slovenian participants placed free access before ease of use).
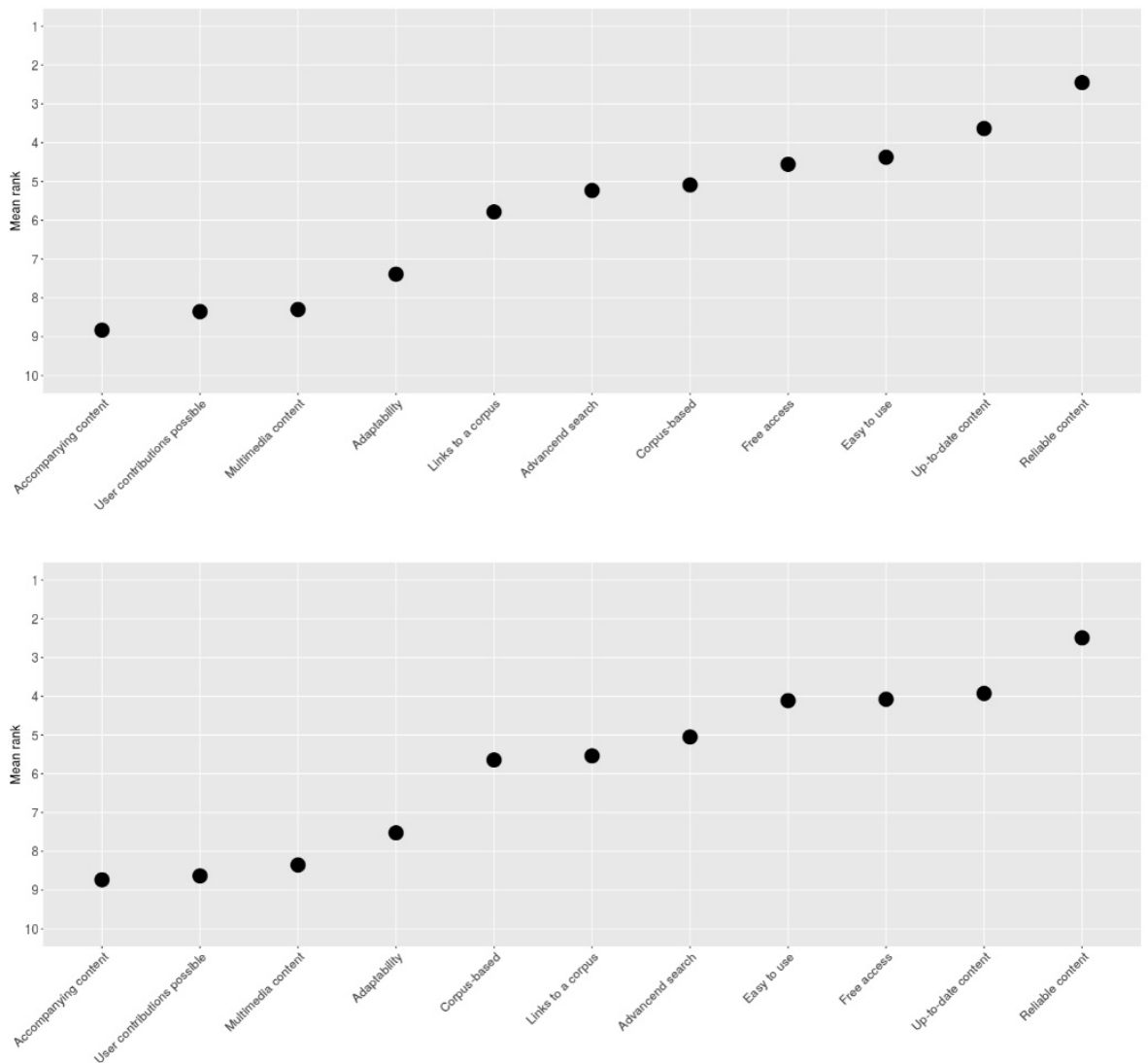

Figure 13: What would you find important in a monolingual dictionary of [language]? (top - European average; bottom - Slovenia) 

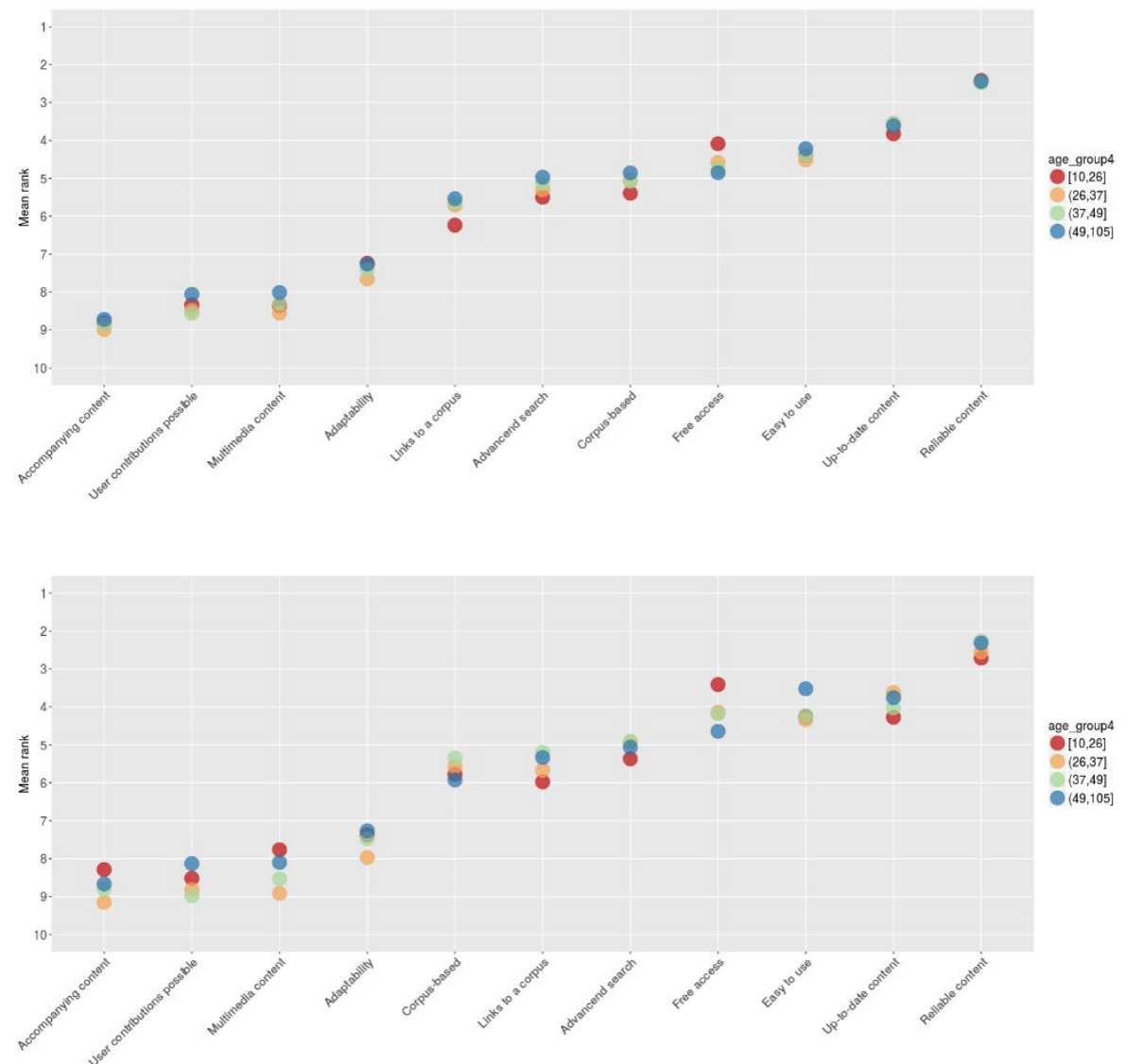

Figure 14: What would you find important in a monolingual dictionary of [language]? (by age groups: top - European average; bottom - Slovenia)

The analysis considering age groups on the European level (Figure 14) does not show any major deviations from the averages; however, in Slovenia this is not the case, as participants under 26 attributed much higher importance to free access, nearly the same as to the first-placed realiability of content.

The comparison of the Slovenian participants with participants from individual countries shows that in some countries up-to-date content is more important (Romania and Macedonia) or almost as important (Italy and Poland) to the participants than reliable content. In Serbia, the UK and Ireland, Finland and 
Germany the participants rate corpus-based characteristic higher, while participants in Georgia, Germany, the Netherlands, and Sweden value advanced search. Most noticeable deviation from the average is displayed by the Macedonian participants, who placed reliability of content only at the 7 th place in terms of importance.

We looked in more detail at the »user contribution possible« category, given that this feature is highly topical in state-of-the-art lexicography. Compared to the Slovenian participants, as well as the European average, more importance is attributed to this characteristic by the participants from Denmark and the Netherlands, and to some extent also by the participants from Finland and Poland (in Poland especially by the participants under 26). On the other hand, the user contributions are the least preferred dictionary characteristic of the participants in Georgia and Romania.

\section{DISCUSSION}

\subsection{Mainly in the European averages, but not always}

The comparative analyses have shown that for many of the questions in the survey the answers of the Slovenian participants were similar to the European averages. This includes the answers on the frequency of dictionary use, situations of dictionary use, actions when they cannot find a word in the dictionary, attitude towards public funding of dictionaries, and the preferential characteristics of monolingual dictionaries. Still, even at these questions certain local deviations could be found, e.g. a considerably higher percentage of the participants from Slovenia turned to other people when they did not find a word in the dictionary (18.3 p.p. above the average). One of the reasons for this could be the antiquated character of Slovenian monolingual reference works, both dictionaries and spelling dictionaries, as already pointed out by Arhar Holdt (2018). Furthermore, in Slovenia other channels, which were not offered as an option in the survey, such as web forums, social network groups (e.g. on 
Facebook), and language consulting are well established. Also relevant seems to be the fact that in Slovenia only one general monolingual dictionary is available, as other countries with this situation have similar percentages of participants that turn to other people in case they do not find a word in the dictionary (Estonia 42.4\%, Finland 46\%, Georgia 43\%).

\subsection{Attitude towards monolingual dictionaries - the influence of publication/sales model?}

As far as the opinions on what a monolingual dictionary means to the general public are concerned, the Slovenian participants slightly differ from the European counterparts. For example, Slovenia is among the countries with the highest percentages of participants that consider the dictionary to be the exhaustive knowledge of language and useful for the general public. The most significant deviation from the European average is found in the percentage of Slovenian participants that consider a monolingual dictionary a national symbol, with only Serbia (28.7\%) and Georgia (26.2\%) ${ }^{15}$ showing higher percentages. It is noteworthy that in these two countries the print format still dominates, in fact in Serbia there were no monolingual dictionaries available in any of the digital formats at the time of the survey.

Furthermore, the comparison of percentages across different options reveals that the opinions of the Slovenian participants are most similar to those of the participants in Germany, Italy, and Serbia - three countries where the commercial model of (print) dictionary sales still dominates.

Similarities of the Slovenian participants with the participants from countries where print dictionaries still dominate continue at the question related to the dictionary that belonged to a family member. Namely, the answers of the Slovenian participants were most similar to those of the participants from

${ }_{15}$ Note that these percentages differ slightly from the percentages reported in Kosem et al. (forthcoming). This is because in this paper raw percentages are given, whereas in the other paper an age-correction process was applied. 
Spain, Norway, Italy, and France. Especially Italy is worth pointing out in this case, as some publishers there (as in Croatia) still use the model of making access to the electronic version of the dictionary conditional on the purchase of the print version, and this exact model was used at the time of the survey for the second edition of the Dictionary of Standard Slovenian Language. ${ }^{16}$ We can assume that this is also, at least partly, the reason behind the low percentage of Slovenian participants that would get rid of the dictionary (recycle it, donate it to the library, or sell it), and at the same time a high percentage of the participants that would keep the dictionary. We should also point out the above-average percentage of the Slovenian participants $\left(2^{\text {nd }}\right.$ among all the countries, behind Georgia) that would keep, but not use the dictionary - this is also in line with the answers of the Slovenian participants about the preferred dictionary format as only $13.2 \%$ reported preferring the print format.

Some insight on the attitudes towards (monolingual) dictionaries is also provided by the answers to the questions about public funding of dictionaries, and about the money the participants are willing to spend on the dictionaries. As far as public funding of dictionaries is concerned, the Slovenian participants overwhelmingly support it and are thus in line with the opinions of the participants across Europe. The finding that is more interesting in this case is that public funding of dictionaries was supported by most participants in all the participating countries, regardless of how dictionaries were funded in their countries at the time of survey. It seems that the participants no longer consider the commercial model as a suitable one for dictionary distribution to the users; the results of the survey supporting this claim are the widespread use of dictionaries in digital formats (which are mostly free) and the wide-spread perception of dictionaries as items of cultural heritage or something that is useful for the general public.

${ }^{16}$ The online version of the dictionary became freely available at the end of 2017. 
The survey participants' expectations that the dictionaries should be freely available or should cost very little are evident from the average amounts they were prepared to pay for dictionaries. This is particularly true of digital dictionary formats, on which the participants were willing to spend on average 5.85 EUR for the desktop version, 4.77 EUR for the online version, and 2.36 for a mobile app. Much more on average (24.94 EUR) were the participants willing to pay for print dictionaries. The Slovenian participants' averages are very close to the European ones for all four formats listed at this question.

However, the picture is not complete without taking dictionary prices into account. Thus, we have conducted an additional comparison between the average price of a print monolingual dictionary and the average amount that the participants were prepared to spend on it. ${ }^{17}$ We have managed to obtain the information on the price of print dictionaries for 14 out of 25 countries (Table 3). ${ }^{18}$ The results show that the Austrian participants were the only ones prepared to pay on average more than the current price of a monolingual dictionary; also close were the participants in Germany and Norway who were prepared to pay on average only slightly less than the average price of a monolingual dictionary. In all other countries the participants were willing to pay (much) less than the average price of a dictionary. The differences between the two amounts were by far the most striking in Slovenia and the Netherlands, mainly on account of a (very) high price of a monolingual dictionary. But while in the Netherlands the dictionary is sold by a commercial publisher and the users have the alternative of using a freely available dictionary by a public institution, in Slovenia, there was (and still is) only one monolingual dictionary

\footnotetext{
17 In this particular comparison, we have only normalized the amounts to EUR. We did not use the purchase power parity as the dictionary prices should be already adjusted to the purchasing power in respective countries.

18 The information was generally provided by local partners, however for some countries we have looked up the prices of dictionaries online (the searches were conducted in July 2018).
} 
available, and since it was publicly funded, the high asking price seems even more questionable.

\begin{tabular}{|l|c|c|c}
\hline & $\begin{array}{c}\text { mean } \\
\text { price } \\
\text { willing to } \\
\text { pay }\end{array}$ & $\begin{array}{c}\text { price of a } \\
\text { monolingual } \\
\text { dictionary }\end{array}$ & \\
\hline Country & 28,1 & 20 & $+8,1$ \\
\hline Austria & 31,9 & 70 & $-38,1$ \\
\hline Belgium & 22,3 & 30 & $-7,7$ \\
\hline Czech Republic & 23,4 & 44 & $-20,6$ \\
\hline Estonia & 29,6 & 70 & $-40,4$ \\
\hline France & 25,0 & 26 & $-1,0$ \\
\hline Germany & 35,3 & 65 & $-29,7$ \\
\hline Greece & 45,6 & 65 & $-19,4$ \\
\hline Italy & 22,4 & 50 & $-27,6$ \\
\hline Macedonia & 25,7 & 180 & $-154,3$ \\
\hline Netherlands & 33,1 & 36 & $-2,9$ \\
\hline Norway & 25,2 & 190 & $-164,8$ \\
\hline Slovenia & 28,6 & 60 & $-31,4$ \\
\hline Spain & 21,7 & 30 & $-8,3$ \\
\hline UK / Ireland & & & \\
\hline
\end{tabular}

Table 3. Differences between dictionary prices and money the participants were willing to spend on a monolingual dictionary (in EUR).

In sum, a greater percentage of the Slovenian participants appreciate the exhaustiveness and informativeness of dictionaries than in other European countries. Furthermore, Slovenia is also among the top countries when it comes to seeing a monolingual dictionary as a national symbol. Slovenian participants support public funding of dictionaries, and are not willing to pay a lot for them, especially when calculated in relation to the price of a dictionary, in which case Slovenians are willing to pay the least of all. Nonetheless, this is not due to their stingy nature but due to the dictionary sales model (online version only available via the purchase of a print copy), which is similar to the models used in countries where commercial dictionary publishers dominate; thus, it is not a very logical choice for Slovenia, where monolingual dictionaries are entirely 
publicly funded. Considering this, it is even more worrying that the dictionarymakers have recently adopted another, even less logical model, by making the publicly funded Slovar sinonimov slovenskega jezika (Dictionary of Slovene Synonyms) available only in the print format for the first three years after publication. At least as far as (not) making dictionaries available to the users goes, Slovenia seems to be definitely unique.

\subsection{Generational particularities}

Also identified were differences between the Slovenian participants and the European averages in terms of different age groups and education groups. Firstly, we found a much lower than average percentage of the Slovenian participants under 26 who would use the relative's (print) dictionary. This corresponds to the low percentage of participants who use the print format, where the percentage of the Slovenian participants under 37 is well below the European average. Still, somewhat surprising is the high percentage of the Slovenian participants under 26 who would keep the dictionary because it belonged to a family member. It appears the Slovenian youth are more sentimental when it comes to their relatives' property, in this case a dictionary, than their European counterparts.

The Slovenian participants under 26 also stood out when asked what they did if they did not find a word in the dictionary. Firstly, a smaller-than-average percentage of the participants turned to another resource (15.6 p.p. below the average). Secondly, above-the-average percentage of them (+3 p.p.; average is $8 \%$ ) reported believing that a word does not exist if it is not in the dictionary. A similar trend for the latter answer can be observed in Estonia (+8 p.p.) and to a lesser degree Finland (+4.2 p.p.), whereas Denmark stands out in this category (+16.9 p.p.).

The similarity with Estonia and Finland is particularly relevant in this case, as in both countries only one monolingual dictionary is available to the users. It could indicate that the absence of choice strengthens the idea among younger 
participants that a dictionary is literally an exhaustive description of language. 19 Relatedly, Estonia stands out in the percentage of participants under 26 (79.7\%) who selected the »exhaustive knowledge of language « option at the question about the meaning of the dictionary. Still, the corresponding percentage of Slovenian participants is lower (64\%), and the percentages of the participants from Denmark (40.5\%) and Finland (31.7\%) even more so. The true reasons for such high percentages of (younger) participants ${ }^{20}$ that believe a word does not exist if not found in the dictionary thus still need to be identified, however it is clearly worth investing time and energy into raising awareness among the users across Europe about the purpose and limitations of dictionaries. ${ }^{21}$

The Slovenian participants under 26 also exhibited noticeable differences from the European averages ( $51.1 \%$ for, $48.9 \%$ against) in their attitudes towards ads in online dictionaries, as the majority were against ads (73.2\%). In this characteristic, they are very similar to the Slovenian participants over 49 . Furthermore, the Slovenian participants under 26 also rated free access of dictionaries nearly as highly as reliability. This is in a way an indication how the future dictionaries of Slovene should be like - freely available and ad-free.

\subsection{Which countries are overall most similar to/different from Slovenia?}

We created a comparative table (Figure 15) based on ranks from all the questions in order to analyse which countries are most similar, or different, to Slovenia in the participants' attitudes towards monolingual dictionaries and in their use. ${ }^{22}$

\footnotetext{
19 A high number of participants that look the word on the web (if it is not in the dictionary) somewhat contradicts this statement.

${ }^{20}$ In fact, a European average of $9 \%$ is already worrying enough.

${ }^{21}$ A similar call has been made by Arhar Holdt (2018).

${ }^{22}$ Due to difficulties in creating ranks for the question on preferred characteristics of a monolingual dictionary, we excluded that question from the analysis.
} 


\begin{tabular}{|c|c|c|c|c|c|c|c|c|c|c|}
\hline $\begin{array}{l}\stackrel{Z}{5} \\
\stackrel{ \pm}{0}\end{array}$ & 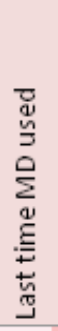 & 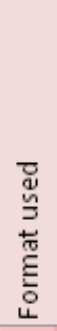 & 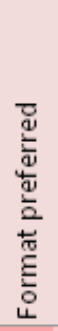 & 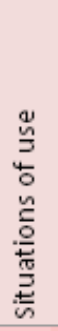 & 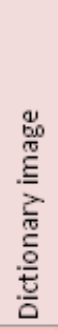 & 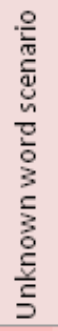 & 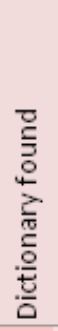 & 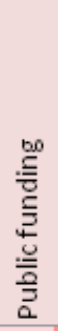 & 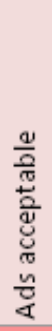 & 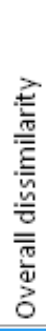 \\
\hline \multirow{7}{*}{$\begin{array}{l}\text { Austria } \\
\text { Basque Country } \\
\text { Belgium } \\
\text { Croatia } \\
\text { Czech Republic } \\
\text { Denmark } \\
\text { Estonia }\end{array}$} & 2 & 8 & 11 & 7 & 8 & 9 & 7 & 4 & 14 & 70 \\
\hline & 1 & 5 & 3 & 9 & 9 & 9 & 11 & 10 & 18 & 74 \\
\hline & 1 & 11 & 9 & 7 & 9 & 7 & 8 & 11 & 2 & 66 \\
\hline & 11 & 13 & 12 & 11 & 7 & 6 & 7 & 9 & 8 & 84 \\
\hline & 7 & 9 & 4 & 7 & 12 & 6 & 6 & 5 & 16 & 71 \\
\hline & 13 & 4 & 7 & 4 & 8 & 6 & 9 & 7 & 9 & 67 \\
\hline & 6 & 2 & 4 & 5 & 9 & 5 & 7 & 7 & 5 & 50 \\
\hline \multirow{2}{*}{$\begin{array}{l}\text { Finland } \\
\text { France }\end{array}$} & 3 & 5 & 4 & 8 & 11 & 6 & 13 & 5 & 6 & 61 \\
\hline & 10 & 9 & 13 & 9 & 11 & 8 & 5 & 9 & 4 & 78 \\
\hline Georgia & 10 & 10 & 13 & 10 & 6 & 5 & 6 & 6 & 19 & 86 \\
\hline Germany & 4 & 5 & 8 & 6 & 6 & 7 & 8 & 7 & 15 & 65 \\
\hline Greece & 8 & 12 & 13 & 6 & 9 & 10 & 13 & 8 & 1 & 79 \\
\hline \multirow{2}{*}{$\begin{array}{l}\text { Israel } \\
\text { Italy }\end{array}$} & 6 & 14 & 18 & 12 & 9 & 5 & 10 & 9 & 11 & 93 \\
\hline & 4 & 12 & 12 & 9 & 8 & 11 & 4 & 11 & 4 & 74 \\
\hline Macedonia & 5 & 8 & 9 & 10 & 8 & 9 & 14 & 8 & 17 & 87 \\
\hline \multirow{2}{*}{$\begin{array}{l}\text { Netherlands } \\
\text { Norway }\end{array}$} & 5 & 15 & 16 & 8 & 10 & 8 & 6 & 9 & 7 & 84 \\
\hline & 11 & 6 & 6 & 6 & 9 & 9 & 3 & 7 & 1 & 57 \\
\hline Poland & 7 & 7 & 10 & 6 & 9 & 9 & 8 & 6 & 12 & 73 \\
\hline Portugal & 3 & 7 & 11 & 10 & 10 & 13 & 12 & 8 & 3 & 76 \\
\hline \multirow{2}{*}{$\begin{array}{l}\text { Romania } \\
\text { Serbia }\end{array}$} & 12 & 6 & 12 & 6 & 8 & 6 & 12 & 7 & 2 & 70 \\
\hline & 9 & 15 & 13 & 12 & 5 & 9 & 15 & 9 & 5 & 91 \\
\hline $\begin{array}{l}\text { Serbia } \\
\text { Slovenia }\end{array}$ & 0 & 0 & 0 & 0 & 0 & 0 & 0 & 0 & 0 & 0 \\
\hline \multirow{2}{*}{ Spain } & 2 & 6 & 10 & 7 & 8 & 8 & 2 & 7 & 10 & 61 \\
\hline & 8 & 13 & 14 & 9 & 8 & 8 & 7 & 7 & 3 & 75 \\
\hline $\begin{array}{l}\text { Sweden } \\
\text { UK / Ireland }\end{array}$ & 9 & 5 & 12 & 7 & 10 & 5 & 8 & 8 & 13 & 76 \\
\hline
\end{tabular}

Figure 15: Overall dissimilarity between Slovenia and the other European countries that participated in the survey.

As the results show, the Slovenian participants seem to be the most similar (or the least dissimilar) to the participants from Estonia; there are no noticeable differences for any of the questions (with perhaps the exception of the question on what a dictionary means to people). The similarities between Slovenia and 
Estonia go beyond our survey: besides both being small countries, only one monolingual dictionary is available to the users, dictionaries are publicly funded, and the digital formats dominate.

Very similar to the Slovenian participants are also participants from Norway, Finland and Spain; however, the differences for certain questions are already more noticeable. For the Norwegian participants, this is the case for the question about the use of monolingual dictionaries, for the Finnish participants for the question about relative's dictionary, and for the Spanish participants for the questions about preferred dictionary format and ads in online dictionaries. The aforementioned three countries are also similar to Slovenia in that dictionaries are publicly funded and that digital formats dominate, with Finland also being a country where only one monolingual dictionary is available.

Somewhat similar to the Slovenian participants are also participants from Germany, Belgium and Denmark. The similarity with participants from Germany and Denmark would have been even higher, if not for the notable differences at the questions about ads in online dictionaries and the use of monolingual dictionaries.

The largest differences can be observed between the Slovenian participants and the participants from Israel and Serbia, where similarities are found in answers to only two questions (different questions for each of the respective countries). The differences are also considerable between the Slovenian participants and the participants from Macedonia, Georgia, Croatia, and the Netherlands. A general observation is that the Slovenian participants seem to differ the most from the participants from countries where (paid) print dictionaries still dominate.

Taking into account only the questions related to the attitudes towards monolingual dictionaries (what a dictionary means to people and what they would do with a dictionary that belonged to a family member), the Slovenian 
participants share the most similarities with participants from Spain (10 rank differences), Georgia, Italy and Norway (12 rank differences), Croatia (14 rank differences) and Sweden (15 rank differences). On the other hand, the Slovenian participants differ the most from the participants from Finland (23 rank differences) and Greece, Macedonia and Portugal (22 rank differences). It is noteworthy that the participants from countries such as Georgia and Croatia, which differ significantly from the Slovenian participants in the overall results, exhibit similarities when it comes to the attitudes towards monolingual dictionaries.

If we limit the comparison to the questions related to the use of monolingual dictionaries (frequency of use, situations, and word not found in a dictionary), the results are again different. Most similar to the Slovenian participants are participants from Belgium (15 rank differences), Estonia (16 rank differences), Austria, Germany and Spain (17 rank differences), and Finland (18 rank differences). On the other hand, most different from the Slovenian participants are the participants from Serbia (29 rank differences), Croatia and France (28 rank differences) and Georgia and Norway (26 rank differences).

We have also conducted comparisons between countries that share a certain characteristic, e.g. a Slavic language, public funding of (monolingual) dictionaries, the important role of spelling dictionaries etc., however no clear patterns were identified. Perhaps the only exception is the dominant dictionary format as the participants from all the countries where the digital formats dominate exhibit a certain level of similarity in survey answers with the participants from Slovenia.

\section{CONCLUSION}

Surveys such as the one described in this paper can shed light on the different uses of and attitudes towards dictionaries in European countries, especially if conducted in many countries and including a large number of participants. The results of this survey have already shown certain patterns in both attitudes 
towards (monolingual) dictionaries and their use. Similarly, the studies of the results from each country will bring much needed insight into dictionary use and needs of the users, considering that in the majority of participating countries studies into dictionary use are rare or non-existent.

Our analysis, which compared Slovenia with other participating countries, showed that in many ways Slovenian users are in many aspects no different from their European counterparts. The main finding is that the users in Slovenia, especially younger generations, rely heavily on digital formats and have thus largely abandoned the print format - this is underpinned by the similarities with "digital" countries such as Estonia and Finland on the one hand, and dissimilarities with countries where print dictionaries still dominate on the other. One aspect in particular that dictionary-makers in Slovenia should take notice of is one in which Slovenia stands out from the other European countries - namely, a very high difference between the price of a (print) monolingual dictionary ${ }^{23}$ and the amount the users are willing to spend on it. That fact, combined with the commercially-oriented sales model used for (publicly funded!) dictionaries, points to the dichotomy between users' needs and dictionary-makers' aims. One can only hope that the results of this survey will facilitate a quick improvement of this situation.

\section{ACKNOWLEDGMENTS}

The authors acknowledge the financial support from the Slovenian Research Agency (infrastructure programs Io-0022 and Io-0051).

23 A very high price of a dictionary can partially be explained by the fact that Slovenia has a rather unique system of public libraries which all have the policy of buying books that are important - and dictionaries certainly are one of them. 


\section{REFERENCES}

Arhar Holdt, Š. (2018): Odnos jezikovnih uporabnikov do splošnih enojezičnih slovarjev: slovenski vidik. Slovenščina 2.o, 6 (1): 1-35. DOI: http://dx.doi.org/10.4312/slo2.0.2017.1.1-35.

Arhar Holdt, Š. (2015): Uporabniške raziskave za potrebe slovenskega slovaropisja: prvi koraki. In V. Gorjanc et al. (eds.): Slovar sodobne slovenščine: problemi in rešitve: 136-148. Ljubljana: Znanstvena založba Filozofske fakultete.

Arhar Holdt, Š., Kosem, I. and Gantar, P. (2016): Dictionary user typology: the Slovenian case. In T. Margarlitadze in G. Meladze (eds.): Lexicography and linguistic diversity: proceedings of the XVII EURALEX International Congress: 179-187. Tbilisi: Ivane Javakhishvili Tbilisi State University. http://euralex2016.tsu.ge/publication2016.pdf.

Bogaards, P. (2003): Uses and users of dictionaries. In P. van Sterkenburg (ur.): A practical Guide to Lexicography: 26-33. Amsterdam in Philadelphia: John Benjamins.

Gliha Komac, N., ed. (2017): Ciljni raziskovalni projekt Jezikovna politika Republike Slovenije in potrebe uporabnikov (raziskovalno poročilo). https://isjfr.zrcsazu.si/sites/default/files/raziskovalno_porocilo_28_11_2017.pdf.

Gliha Komac, N., Jakop, N., Ježovnik, J., Klemenčič, S., Krvina, D., Ledinek, N., Mirtič, T., Perdih, A., Petric, Š., Snoj, M., and Žele, A. (2015): Osnutek koncepta novega razlagalnega slovarja slovenskega knjižnega jezika. Različica 1.1. Ljubljana: Inštitut za slovenski jezik Frana Ramovša; Znanstvenoraziskovalni center Slovenske akademije znanosti in umetnosti.

Gorjanc, V., Gantar, P., Kosem, I. and Krek, S., eds. (2015): Slovar sodobne slovenščine: problemi in rešitve. Ljubljana: Znanstvena založba 
Filozofske fakultete.

Gorjanc, V., Gantar, P., Kosem, I. and Krek, S., eds. (2016): Dictionary of modern Slovene: problems and solutions. Ljubljana: Ljubljana University Press, Faculty of Arts.

Klosa, A., Koplenig, A. and Töpel, A. (2014): 'Benutzerwünsche und Meinungen zu Dem Monlingualem Deutschen Onlinewörterbuch Elexiko. In C. Müller-Spitzer (ed.): Using Online Dictionaries. (Lexicographica Series Maior 145.): 281-384. Berlin: Walter de Gruyter.

Kosem, I., Lew, R., Müller-Spitzer, C. and Wolfer, S. (2017). The European survey of dictionary use. In: Electronic lexicography in the 21st century: lexicography from scratch: 53. Leiden: Dutch Language Institute; Brno: Lexical Computing; Ljubljana: Trojina Institute for Applied Slovene Studies.

Kosem, I., Lew, R., Müller-Spitzer, C., Ribeiro Silveira, M., Wolfer, S. et al. (2018). The image of the monolingual dictionary across Europe: Results of the European survey of dictionary use and culture. International Journal of Lexicography. Advanced access: https://doi.org/10.1093/ijl/ecyo22.

Kosem, I., Gantar, P. and Krek, S. (2013): Automation of lexicographic work: an opportunity for both lexicographers and crowd-sourcing. In I. Kosem et al. (eds.): Electronic lexicography in the 21st century: thinking outside the paper: 32-48. Ljubljana: Trojina, Institute for Applied Slovene Studies; Tallinn: Eesti Keele Instituut.

Krek, S., Kosem, I. and Gantar, P. (2013): Predlog za izdelavo Slovarja sodobnega slovenskega jezika. Izd. 1.1. Ljubljana: s. n. http://www.sssj.si/datoteke/Predlog_SSSJ_v1.1.pdf.

Lew, R. (2015): Research into the Use of Online Dictionaries. International 
Journal of Lexicography, 28 (2): 232-253.

Logar, N. (2009): Slovenski splošni in terminološki slovarji: za koga? In M. Stabej (ed.): Infrastruktura slovenščine in slovenistike. Obdobja 28: 225-231. Ljubljana: Znanstvena založba Filozofske fakultete.

Logar, N., Gantar, P., Arhar Holdt, Š., Gorjanc, V., Kosem, I., Krek, S. and Stabej, M. (2017): Odziv na “Anketo o slovenščini” projekta Jezikovna politika Republike Slovenije in potrebe uporabnikov. Slovenščina 2.o, 5 (1): 27-37.

Müller-Spitzer, C., ed. (2014): Using Online Dictionaries. Berlin, Boston: De Gruyter Mouton.

Rozman, T. (2004): Upoštevanje ciljnih uporabnikov pri izdelavi enojezičnega slovarja za tujce. Jezik in slovstvo, 49 (3/4): 63-75.

Stabej, M. (2009): Slovarji in govorci: kot pes in mačka? Jezik in slovstvo, 54 (3/4): 115-138.

Tarp, S. (2009): Reflections on Lexicographical User Research. Lexikos 19 (1): 275-296. 


\section{ODNOS SLOVENSKIH JEZIKOVNIH UPORABNIKOV DO SPLOŠNIH ENOJEZIČNIH SLOVARJEV: MEDNARODNI VIDIK}

V raziskavi o odnosu do (enojezičnih) slovarjev in njihovi rabi, ki je bila izvedena leta 2017 in je trenutno največja tovrstna raziskava med uporabniki (pa tudi neuporabniki) slovarjev, je sodelovala tudi Slovenija. Pričujoči prispevek se osredotoča na primerjalno analizo rezultatov, v kateri so slovenski rezultati po eni strani primerjani z evropskimi povprečji, po drugi strani pa z rezultati posameznih držav. Analize kažejo, da so pri mnogih vprašanjih slovenski uporabniki bolj ali manj v evropskem povprečju, čeprav pri določenih vprašanjih prihaja do generacijskih razlik, zlasti pri mlajših od 26 let (npr. nadpovprečna sentimentalna navezanost na sorodnikov slovar, nadpovprečno prepričanje, da beseda ne obstaja, če je ni v slovarju, skoraj enako vrednotenje prostega dostopa in zanesljivosti). Slovenski uporabniki pa v primerjavi z evropskim povprečjem nadpovprečno preferirajo digitalne slovarske oblike, zlasti računalniško, in podpovprečno preferirajo tiskano obliko slovarja. Naklonjenost digitalnemu potrjuje tudi velika podobnost $\mathrm{v}$ skoraj vseh odgovorih z uporabniki iz Estonije in Finske, pa tudi ostalimi državami, kjer prevladujejo digitalni mediji. Hkrati so slovenski uporabniki med vodilnimi v deležu tistih, ki imajo slovar za nacionalni simbol, kar je po rezultatih raziskave bolj tipično za uporabnike iz držav, kjer še vedno prevladujejo tiskani slovarji. Najbolj izrazito pa slovenski uporabniki oz. slovenska slovarska situacija izstopa v razliki med ceno (tiskanega) enojezičnega slovarja in zneskom, ki so ga zanj pripravljeni odšteti uporabniki (ki je sicer na ravni evropskega povprečja), saj je ta razlika največja med vsemi državami, ki so sodelovale v raziskavi. Od mnogih pomembnih ugotovitev, ki jih za slovenske izdelovalce slovarjev prinaša ta prispevek, je ta gotovo eden najbolj ključnih.

Keywords: slovarski uporabniki, evropska raziskava, raba slovarjev, splošni enojezični slovar, slovaropisje 
To delo je ponujeno pod licenco Creative Commons: Priznanje avtorstvaDeljenje pod enakimi pogoji 4.o Mednarodna.

This work is licensed under the Creative Commons Attribution-ShareAlike 4.0 International.

https://creativecommons.org/licenses/by-sa/4.o/

(c) $\underset{\mathrm{BY}}{\mathrm{BA}}$ 